Supplement of Biogeosciences, 18, 4021-4037, 2021 https://doi.org/10.5194/bg-18-4021-2021-supplement (C) Author(s) 2021. CC BY 4.0 License.

(c) (1)

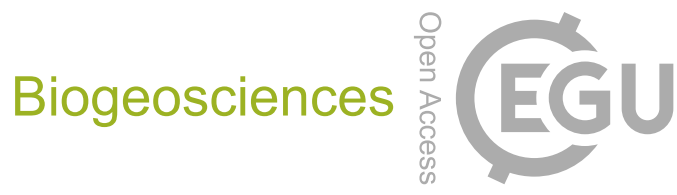

Supplement of

\title{
Organic phosphorus cycling may control grassland responses to nitrogen deposition: a long-term field manipulation and modelling study
}

Christopher R. Taylor et al.

Correspondence to: Christopher R. Taylor (ctaylor8@ sheffield.ac.uk)

The copyright of individual parts of the supplement might differ from the article licence. 


\section{Supplementary methods}

\section{Empirical data collection}

The following section describes the methods used to collect data from Wardlow to be used in calibrating the model and later testing its performance. It also details how empirical data was converted into model-compatible data. The variables for which data were collected are aboveground biomass (converted to aboveground biomass carbon for the model), soil organic carbon and soil organic nitrogen. Total soil phosphorus data was taken from work previously carried out at Wardlow. Data were collected from mesocosms extracted from the acidic and limestone grasslands at Wardlow.

\subsection{Biomass data}

Biomass data from the acidic and limestone grasslands at Wardlow is not used within the cost function to determine the $P_{\text {weatho }}$ and $P_{\text {cleaveMax }}$ values. As it was not included, it could be used to blindly assess the model's performance at simulating biomass carbon stocks.

To estimate total standing biomass stocks for the acidic and limestone grasslands, two separate harvests were collected and summed; a 'partial' and a 'full' harvest. In the former, all above ground biomass down to a height of $5 \mathrm{~cm}$ in the acidic and $2.5 \mathrm{~cm}$ in the limestone is harvested, with a frequency of twice a year, once in the summer and again in autumn as described by Phoenix et al. (2003). The full clip harvest removes all standing biomass down to the soil surface from a small area $\left(0.07 * 0.07 \mathrm{~m}^{2}\right)$ of each mesocosm. This is done once a year and is never repeated in the same spot.

To convert the biomass data from a single year into the model-equivalent above-ground carbon stocks, the following Equation (Eq. S1) was used:

$$
\frac{\left(P_{1} \cdot \frac{1}{A_{P}}\right)+\left(P_{2} \cdot \frac{1}{A_{P}}\right)+\left(F \cdot \frac{1}{A_{F}}\right)}{2}
$$

Here, $P_{1}$ and $P_{2}$ represent the first (spring) and second (summer) partial harvest biomass dry weight (grams) and $F$ represents the full harvest biomass by dry weight. $A_{P}$ and $A_{F}$ are the areas from which the biomass was harvested and are $0.35 * 0.35 \mathrm{~m}^{2}$ and $0.07 * 0.07 \mathrm{~m}^{2}$ respectively. Dividing 1 by the harvest area converts the data from grams to grams per metre squared. Finally, as per Chapin et al. (2011), we assume $50 \%$ of dry biomass is carbon and hence divide the total above ground biomass by 2 to estimate the above ground carbon stocks.

The equivalent modelled data is the annual sum of the soft tissue carbon for plant types 1 and 2, which represent two end-members with different C: $\mathrm{N}$ ratios (see Davies et al. 2016b for more details). 


\subsection{Soil organic carbon and soil nitrogen data collection}

Six replicates for each grassland-treatment combination where analysed for soil organic carbon and total soil nitrogen content (note that total soil nitrogen is assumed equivalent in pool size to the organic nitrogen pool within the model). The deeper soil profile of the acidic grasslands produces two distinct horizons; organic and mineral, whereas the limestone grassland consists of a single humic horizon. As such, six replicates were taken from each of the two distinct acidic horizons, which were sampled to a depth of $20 \mathrm{~cm}$.

The depth of each acidic horizon was measured but could be approximately distinguished into depths of $0-10 \mathrm{~cm}$ and $10-20 \mathrm{~cm}$ for organic and mineral horizons respectively. The limestone horizon depth was classified as $0-10 \mathrm{~cm}$ depth. To account for spatial heterogeneity within soil conditions at the field site, 2 replicates of each block (A, B or $C$ ) were taken for sampling. Acidic samples from both horizons were paired.

Soil organic carbon and total nitrogen content were determined by acid stripping soil with hydrochloric acid to remove carbonates, a method adapted from Hedges and Stern's (1984) approach. Approximately $5 \mathrm{~g}$ of oven-dried soil was homogenised in a pestle and mortar. A sub sample of roughly $60 \mathrm{mg}$ of this was placed in a $1.5 \mathrm{ml}$ Starstedt Eppendorf tube prior to acid stripping. $700 \mu \mathrm{l}$ of $6 \mathrm{M}$ hydrochloric acid was added and stirred. The tubes were left for 15 minutes before a further $100 \mu \mathrm{l}$ of acid was added and the mixture stirred again before leaving in a fume cupboard for 24 hours. After 24 hours, the samples were mixed again and put in a Techne DB 200/3 Dri-Block for 24 hours at 105 degrees ${ }^{\circ} \mathrm{C}$ until the acid had evaporated. The pellets were crushed into a fine powder prior to analysis in the isotope-ratio mass spectrometer as in Harris et al. (2001).

\subsection{Converting empirical to modelled $C$ and $N$ data}

The modelled organic carbon and nitrogen units represent total stocks in grams per metre squared as opposed to percent dry weight for the empirical data. To incorporate empirical data into the model, a number of adjustments were required to make the data model-compatible.

Firstly, the mass of soil in the organic and mineral horizons ( $\mathrm{MH}_{\mathrm{O}}$ and $\mathrm{MH}_{\mathrm{M}}$ respectively) was calculated by multiplying each treatment's mean horizon depth $\left(\mathrm{DH}_{\mathrm{O}}, \mathrm{DH}_{\mathrm{M}}\right)$ by its bulk density $\left(\mathrm{BD}_{\circ}\right.$, $B D_{M}$ ). To convert this to grams per metre squared, this value was multiplied by 10,000 (Eq. S2a, S2b).

The mass (grams) of carbon in each horizon $\left(\mathrm{MC}_{\mathrm{O}}, \mathrm{MC}_{\mathrm{M}}\right.$ ) was calculated by multiplying the horizon mass derived from Eq. S2a and S2b by the empirical organic carbon percentage ( $\mathrm{SOC}_{\mathrm{empo}}, \mathrm{SOC}_{\mathrm{empM}}$ ). As the empirical data is presented as a percentage, the data were multiplied by 0.01 (Eq. S3a, S3b).

Finally, to calculate the organic carbon stocks within the model, the differing depths of the topsoils of the empirical versus modelled grassland needed to be considered. The total soil depths were 20 $\mathrm{cm}$ and $10 \mathrm{~cm}$ for the acidic and limestone grasslands respectively but the modelled topsoil, which corresponds to the layer of soil that plants can interact with, was $15 \mathrm{~cm}$.

As the limestone grassland soil profile rarely exceeds $15 \mathrm{~cm}$ in depth, it was assumed that the empirical SOC value (in $\mathrm{g} \mathrm{m}^{-2}$ ) applied to the whole modelled topsoil component. Conversely for the acidic profile which exceeds $15 \mathrm{~cm}$, adjustments were required to ensure that the mineral horizon was not overrepresented and thus SOC underestimated. To account for this, the mass of carbon in the organic horizon was added to half the mass of carbon in the mineral to give an approximation of the carbon in the top $15 \mathrm{~cm}$ of soil (Eq. S4). 


$$
\begin{gathered}
M H_{O}=D H_{O} \cdot B D_{O} \cdot 10,000 \\
M H_{M}=D H_{M} \cdot B D_{M} \cdot 10,000 \\
M C_{O}=M H_{O} \cdot S O C_{e m p o} \cdot 0.01 \\
M C_{M}=M H_{M} \cdot S O C_{e m p M} \cdot 0.01 \\
S O C_{\text {mod }}=M C_{O}+\frac{M C_{M}}{2}
\end{gathered}
$$

The same process was used to convert empirical organic $\mathrm{N}$ into model-compatible $\mathrm{N}$ data.

To convert the $\mathrm{C}$ and $\mathrm{N}$ data from the limestone grassland, a similar procedure was followed as in Equations S2 to S4 but with a single horizon and no adjustment to soil depth (Eq. S5 and S6):

$$
\begin{gathered}
M H=D H \cdot B D \cdot 10,000 \\
M C=M H . S O C_{e m p} \cdot 0.01
\end{gathered}
$$

\subsection{Total soil phosphorus data}

Total soil phosphorus (TP) data was compared to TP simulated by the model in figure 2, but soil organic $\mathrm{P}$ is presented and analysed in figure 4 and data pertaining to it. This is due to total but not soil organic $P$ data being available for Wardlow. To calculate total soil P in the model, the SOP pool is added to the sorbed $P$ pool.

Due to time constraints, total soil phosphorus data was not collected and instead we used P data collected previously from the same two grasslands used within the current study (Horswill et al. 2008). These data were in $\mathrm{mmol} \mathrm{kg}^{-1}$ and like soil $\mathrm{C}$ and $\mathrm{N}$ data, were converted into the modelcompatible $\mathrm{g} \mathrm{m}^{-2}$. First, the TP data was divided by 1000 to give the value in moles $\mathrm{kg}^{-1}$ and multiplied by the atomic mass of $\mathrm{P}(\mathrm{AM} \mathrm{P})$ to convert to $\mathrm{g} \mathrm{kg}^{-1}$ (Eq. S7). This divides by 10 to give $\% \mathrm{P}$ and from there the same methods can be applied from the $\mathrm{C}$ and $\mathrm{N}$ conversions detailed above.

$$
P\left(g \mathrm{~kg}^{-1}\right)=\frac{P\left(\mathrm{mmol} \mathrm{kg}{ }^{-1}\right)}{1000} \cdot A M_{P}
$$




\section{Supplementary data}

\subsection{Empirical $C, N$ and $P$ data}

These data are the empirical estimates of $\mathrm{C}, \mathrm{N}$ and $\mathrm{P}$ stocks as calculated in section 1 above.

Table S1: Mean empirical estimates of above ground biomass carbon (AGB C), soil organic carbon (SOC), soil organic nitrogen (SON) and total soil phosphorus (TP). All nutrient treatments ( $O N, L N, H N$ and P) for which there are data are presented for both grasslands. Data are in grams per metre squared and the standard error of the mean is in brackets. Absent data are denoted by NA.

\begin{tabular}{llrrrr}
\hline \multirow{2}{*}{ Grassland } & Nutrient & \multicolumn{4}{c}{ Mean stock (+/- SE) } \\
\cline { 3 - 6 } & & \multicolumn{1}{c}{ ON } & LN & HN & \multicolumn{1}{c}{ P } \\
\hline Acidic & AGB C & $478(86)$ & $614(93)$ & $718(66)$ & $744(23)$ \\
& SOC & $4740(228)$ & $4908(110)$ & $6273(226)$ & $5479(165)$ \\
& SON & $403(29)$ & $416(24)$ & $527(26)$ & $448(51)$ \\
& TP & $123(22)$ & NA & $83(18)$ & NA \\
\hline Limestone & AGB C & $332(25)$ & $419(45)$ & $330(33)$ & $582(181)$ \\
& SOC & $6151(288)$ & $5639(380)$ & $6375(371)$ & $6762(739)$ \\
& SON & $543(22)$ & $508(36)$ & $609(31)$ & $591(63)$ \\
& TP & $85(2.9)$ & NA & $93(5.7)$ & NA \\
\hline
\end{tabular}

\subsection{Field experiment description}

Table S2: Soil and vegetation characteristics of the Wardlow grasslands

\begin{tabular}{ccccc}
\hline $\begin{array}{c}\text { Grassland } \\
\text { type }\end{array}$ & Soil type & Soil texture & $\begin{array}{c}\text { Vegetation } \\
\text { type }\end{array}$ & NVC \\
\hline Acid & $\begin{array}{c}\text { Paleo-agrillic } \\
\text { brown earth }\end{array}$ & Silt loam & $\begin{array}{c}\text { Acidic } \\
\text { grassland }\end{array}$ & $\begin{array}{c}\text { U4e, Festuca- } \\
\text { Agrostis- } \\
\text { Galium }\end{array}$ \\
Limestone & $\begin{array}{c}\text { Humic } \\
\text { rendzina }\end{array}$ & Sandy loam & $\begin{array}{c}\text { Limestone } \\
\text { grassland }\end{array}$ & $\begin{array}{c}\text { CG2d, } \\
\text { Festuca- } \\
\text { Avenula }\end{array}$ \\
\hline
\end{tabular}




\subsection{Input drivers}

Table S3: A summary of the input driver data used to run the model and their sources. All units are presented as they are included in the model, following any necessary required conversions.

\begin{tabular}{|c|c|c|c|}
\hline Variable & Units & Notes & Source \\
\hline $\begin{array}{l}\text { Mean quarterly } \\
\text { temperature }\end{array}$ & ${ }^{\circ} \mathrm{C}$ & $\begin{array}{l}\text { The nearest weather station to Wardlow } \\
\text { was selected using Pythagoras' theorem }\end{array}$ & $\begin{array}{l}\text { UKPC09 Met office } \\
\text { CEDA database }\end{array}$ \\
\hline $\begin{array}{l}\text { Mean annual } \\
\text { precipitation }\end{array}$ & $\mathrm{mm}$ & (same as above) & $\begin{array}{l}\text { UKPC09 Met office CEDA } \\
\text { database }\end{array}$ \\
\hline $\mathrm{N}$ deposition & $\mathrm{g} \mathrm{m}^{-2}$ year $^{-1}$ & $\begin{array}{l}\text { Nearest site to Wardlow's grid } \\
\text { reference }\end{array}$ & CEH deposition maps \\
\hline BC deposition & $\mathrm{g} \mathrm{m}^{-2}$ year $^{-1}$ & (same as above) & CEH deposition maps \\
\hline S deposition & $\mathrm{g} \mathrm{m}^{-2}$ year $^{-1}$ & (same as above) & CEH deposition maps \\
\hline $\begin{array}{l}\text { Plant functional } \\
\text { type history }\end{array}$ & - & $\begin{array}{c}\text { Annual basis, determined by pollen } \\
\text { stratigraphy - specific history detailed in } \\
\text { main text }\end{array}$ & Taylor et al. (1994) \\
\hline Nutrient additions & $\mathrm{g} \mathrm{m}^{-2}$ year $^{-1}$ & Details of seasonal fertiliser additions & Morecroft et al. (1994) \\
\hline
\end{tabular}




\section{Results}

\subsection{Varying phosphorus source parameters}

The below differences were calculated using the empirical data (Obs) as the original data, hence a positive difference (Diff) or percentage change (Percent) means the simulated data (Sim) is that much less and a negative percent value means the simulated data is that much higher than the observed. The Percent column was calculated by dividing the Diff column by the Obs and multiplying by 100. Note that the 'Obs' column in Table S5 is a repeat of the empirical data in Table S4 but is provided again for convenience. Table $\mathrm{S} 6$ provides the mean of each nutrient from Table $\mathrm{S} 5$ and is the data plotted in Figure 2.

Table S4: A collation of the observed data (Obs) and simulated data (Sim) for soil organic carbon (C), soil organic nitrogen ( $\mathrm{N}$ - assumed equivalent to total soil $\mathrm{N}$ ), total soil phosphorus $(\mathrm{P})$ and aboveground biomass carbon (AGB_C). The SE column represents the standard error of the mean of observations and are the error bars plotted on Figure 2. The difference between the observed and simulated data (Diff) and the percentage difference (Percent) are present. All data are in grams per metre squared.

\begin{tabular}{|c|c|c|c|c|c|c|c|}
\hline Treatment & Nutrient & Obs & Sim & SE & Grassland & Diff & Percent \\
\hline 'ON' & 'P' & 123.10 & 46.01 & 21.92 & 'Acid' & 77.09 & 62.63 \\
\hline 'LN' & 'P' & $\mathrm{NaN}$ & 45.09 & $\mathrm{NaN}$ & 'Acid' & $\mathrm{NaN}$ & $\mathrm{NaN}$ \\
\hline 'HN' & 'P' & 82.60 & 44.02 & 17.61 & 'Acid' & 38.58 & 46.70 \\
\hline 'P' & 'P' & $\mathrm{NaN}$ & 77.05 & $\mathrm{NaN}$ & 'Acid' & $\mathrm{NaN}$ & $\mathrm{NaN}$ \\
\hline 'ON' & 'C' & 4739.95 & 6938.16 & 228.04 & 'Acid' & -2198.22 & -46.38 \\
\hline 'LN' & 'C' & 4907.84 & 7639.43 & 110.24 & 'Acid' & -2731.59 & -55.66 \\
\hline 'HN' & 'C' & 6273.48 & 8205.12 & 225.50 & 'Acid' & -1931.64 & -30.79 \\
\hline 'P' & 'C' & 5478.91 & 6938.16 & 165.48 & 'Acid' & -1459.25 & -26.63 \\
\hline 'ON' & 'N' & 403.06 & 396.68 & 28.51 & 'Acid' & 6.38 & 1.58 \\
\hline 'LN' & 'N' & 415.52 & 430.59 & 23.62 & 'Acid' & -15.06 & -3.62 \\
\hline 'HN' & 'N' & 527.08 & 528.32 & 25.57 & 'Acid' & -1.24 & -0.23 \\
\hline 'P' & 'N' & 447.92 & 396.68 & 51.45 & 'Acid' & 51.24 & 11.44 \\
\hline 'ON' & 'P' & 85.30 & 94.14 & 2.85 & 'Lime' & -8.84 & -10.36 \\
\hline 'LN' & 'P' & $\mathrm{NaN}$ & 94.14 & $\mathrm{NaN}$ & 'Lime' & $\mathrm{NaN}$ & $\mathrm{NaN}$ \\
\hline 'HN' & 'P' & 92.60 & 94.14 & 5.70 & 'Lime' & -1.54 & -1.66 \\
\hline 'P' & 'P' & $\mathrm{NaN}$ & 124.29 & $\mathrm{NaN}$ & 'Lime' & $\mathrm{NaN}$ & $\mathrm{NaN}$ \\
\hline 'ON' & 'C' & 6151.48 & 6588.09 & 287.75 & 'Lime' & -436.60 & -7.10 \\
\hline 'LN' & 'C' & 5639.41 & 6560.32 & 379.51 & ‘Lime’ & -920.91 & -16.33 \\
\hline 'HN' & 'C' & 6374.83 & 6505.15 & 370.76 & 'Lime' & -130.32 & -2.04 \\
\hline 'P' & 'C' & 6762.00 & 6950.21 & 739.31 & 'Lime' & -188.21 & -2.78 \\
\hline 'ON' & 'N' & 543.12 & 438.74 & 22.33 & 'Lime' & 104.38 & 19.22 \\
\hline 'LN' & 'N' & 508.35 & 465.02 & 35.63 & 'Lime' & 43.32 & 8.52 \\
\hline 'HN' & 'N' & 609.07 & 501.41 & 30.94 & 'Lime' & 107.66 & 17.68 \\
\hline 'P' & 'N' & 590.72 & 437.41 & 62.89 & 'Lime' & 153.31 & 25.95 \\
\hline 'ON' & 'AGB_C' & 477.60 & 576.18 & 85.67 & 'Acid' & -98.58 & -20.64 \\
\hline 'LN' & 'AGB_C' & 613.59 & 772.84 & 92.64 & 'Acid' & -159.24 & -25.95 \\
\hline 'HN' & 'AGB_C' & 717.98 & 915.70 & 66.00 & 'Acid' & -197.72 & -27.54 \\
\hline 'P' & 'AGB_C' & 743.92 & 576.18 & 23.35 & 'Acid' & 167.74 & 22.55 \\
\hline 'ON' & 'AGB_C' & 332.05 & 438.56 & 24.94 & 'Lime' & -106.51 & -32.08 \\
\hline 'LN' & 'AGB_C' & 419.09 & 427.96 & 44.92 & 'Lime' & -8.86 & -2.11 \\
\hline 'HN' & 'AGB_C' & 330.24 & 406.79 & 33.40 & 'Lime' & -76.55 & -23.18 \\
\hline 'P' & 'AGB_C' & 582.26 & 530.69 & 181.94 & 'Lime' & 51.56 & 8.86 \\
\hline
\end{tabular}


Table S5: Mean percentage difference across nutrient treatments between observed and simulated data, derived from Table S5. The SE is the standard error of the mean of each nutrient - grassland combination.

\begin{tabular}{cccc}
\hline Nutrient & Grassland & Mean & SE \\
\hline 'C' & 'Acid' & -39.86 & 6.77 \\
'N' & 'Acid' & 2.29 & 3.23 \\
'P' & 'Acid' & 54.67 & 7.96 \\
'AGB_C' & 'Acid' & -12.90 & 11.91 \\
'C' & 'Lime' & -7.06 & 3.28 \\
'N' & 'Lime' & 17.84 & 3.59 \\
'P' & 'Lime' & -6.01 & 4.35 \\
'AGB_C' & 'Lime' & -12.13 & 9.40 \\
\hline
\end{tabular}




\subsection{The limiting nutrient through time and 3.3. Modelled trends and responses to nutrient additions}

The below section is combined into one with a header different from those in the main manuscript as the data cross over and are used in different sections. The below tables (S7 - S14) are used to construct the $\mathrm{C}, \mathrm{N}$ and $\mathrm{P}$ budgets (Fig 5 ) and provide additional information about the limiting nutrient and organic $\mathrm{P}$ access. Figure $\mathrm{S} 1$ explicitly examines the organic $\mathrm{P}$ access of each grassland under different nutrient manipulations. Tables S15 - S17 relate to figure 4 and look at how plant and soil $\mathrm{C}, \mathrm{N}$ and $\mathrm{P}$ have responded to $\mathrm{N}$ deposition and experimental nutrient additions.

\section{Acidic}

\section{Carbon budget}

Table S6: Carbon budget for the modelled acidic grassland in 2020, under different nutrient additions in grams per metre squared. The table shows the sizes of and changes to different $\mathrm{C}$ pools within the model following nutrient manipulation.

\begin{tabular}{cccc}
\hline Treatment & Subsoil SOC & Topsoil SOC & Biomass C \\
\hline ON & 2748.84 & 6987.28 & 1146.51 \\
LN & 2789.99 & 7789.21 & 1560.98 \\
HN & 2820.38 & 8425.72 & 1853.93 \\
P & 2748.84 & 6987.28 & 1146.51 \\
\hline
\end{tabular}

\section{Nitrogen budget}

Table S7: Nitrogen budget for the modelled acidic grassland in 2020, under different nutrient additions in grams per metre squared. The table shows the sizes of and changes to different $\mathrm{N}$ pools within the model following nutrient manipulation.

\begin{tabular}{cccccc}
\hline Treatment & Subsoil SON & Topsoil SON & Available N & Fixed N & Biomass N \\
\hline ON & 175.37982 & 399.98694 & 15.56958 & 0 & 30.18691 \\
LN & 176.53285 & 438.88054 & 22.47605 & 0 & 45.50620 \\
HN & 179.72432 & 546.54556 & 40.40837 & 0 & 61.93123 \\
P & 175.37982 & 399.98694 & 15.56958 & 0 & 30.18691 \\
\hline
\end{tabular}


Phosphorus budget

Table S8: Phosphorus budget for the modelled acidic grassland in 2020, under different nutrient additions in grams per metre squared. The table shows the sizes of and changes to different $P$ pools within the model following nutrient manipulation.

\begin{tabular}{cccccccc}
\hline Treatment & Weatherable & $\begin{array}{c}\text { Subsoil } \\
\text { sorbed }\end{array}$ & $\begin{array}{c}\text { Subsoil } \\
\text { SOP }\end{array}$ & $\begin{array}{c}\text { Topsoil } \\
\text { sorbed }\end{array}$ & $\begin{array}{c}\text { Topsoil } \\
\text { SOP }\end{array}$ & Available & Biomass P \\
\hline ON & 15.8916 & 2.5512 & 7.4716 & 7.8463 & 38.1554 & 1.1155 & 3.0187 \\
LN & 15.8916 & 2.5512 & 7.5037 & 7.8463 & 36.4937 & 1.3903 & 4.5506 \\
HN & 15.8916 & 2.5512 & 7.5344 & 7.8463 & 34.7023 & 1.6477 & 6.1931 \\
P & 15.8916 & 4.2524 & 8.2002 & 66.8623 & 67.4159 & 5.3296 & 3.0187 \\
\hline
\end{tabular}

Phosphorus cleaving

Table S9: $P_{\text {CleaveMax }}$ per growing season for the acidic grassland, and the amount of $P$ cleaved from the SOP pool in 2020 under different nutriment treatments.

\begin{tabular}{ccc}
\hline Treatment & $\begin{array}{c}\boldsymbol{P}_{\text {CleaveMax }}\left(\mathrm{g} \mathrm{m}^{-2} \text { per growing }\right. \\
\text { season) }\end{array}$ & P cleaved in $\mathbf{2 0 2 0}\left(\mathbf{g ~ m}^{-\mathbf{2}}\right)$ \\
\hline ON & 0.3162 & 0.221 \\
LN & 0.3162 & 0.429 \\
HN & 0.3162 & 0.632 \\
P & 0.3162 & 0.000 \\
\hline
\end{tabular}




\section{Limestone}

Carbon budget

Table S10: Carbon budget for the modelled limestone grassland in 2020, under different nutrient additions in grams per metre squared. The table shows the sizes of and changes to different $C$ pools within the model following nutrient manipulation.

\begin{tabular}{cccc}
\hline Treatment & Subsoil SOC & Topsoil SOC & Biomass C \\
\hline ON & 2976.48 & 6613.41 & 869.21 \\
LN & 2973.17 & 6583.32 & 848.10 \\
HN & 2966.10 & 6523.45 & 806.09 \\
P & 3000.39 & 7015.10 & 1060.74 \\
\hline
\end{tabular}

\section{Nitrogen budget}

Table S11: Nitrogen budget for the modelled limestone grassland in 2020, under different nutrient additions in grams per metre squared. The table shows the sizes of and changes to different $\mathrm{N}$ pools within the model following nutrient manipulation.

\begin{tabular}{cccccc}
\hline Treatment & Subsoil SON & Topsoil SON & Available N & Fixed N & Biomass N \\
\hline ON & 207.75693 & 441.27447 & 14.14192 & 0 & 17.91213097 \\
LN & 208.87098 & 469.47608 & 19.68183 & 0 & 17.9009423 \\
HN & 209.08553 & 507.64361 & 30.58437 & 0 & 17.86741168 \\
P & 207.68085 & 440.32884 & 14.41858 & 0 & 24.08056454 \\
\hline
\end{tabular}

\section{Phosphorus budget}

Table S12: Phosphorus budget for the modelled limestone grassland in 2020, under different nutrient additions in grams per metre squared. The table shows the sizes of and changes to different $P$ pools within the model following nutrient manipulation.

\begin{tabular}{cccccccc}
\hline Treatment & Weatherable & $\begin{array}{c}\text { Subsoil } \\
\text { sorbed }\end{array}$ & $\begin{array}{c}\text { Subsoil } \\
\text { SOP }\end{array}$ & $\begin{array}{c}\text { Topsoil } \\
\text { sorbed }\end{array}$ & $\begin{array}{c}\text { Topsoil } \\
\text { SOP }\end{array}$ & Available & Biomass P \\
\hline ON & 31.7832 & 7.9625 & 12.9875 & 37.1784 & 56.9501 & 1.0327 & 1.7912 \\
LN & 31.7832 & 7.9653 & 12.9860 & 37.2774 & 56.8487 & 1.0245 & 1.7901 \\
HN & 31.7832 & 7.9711 & 12.9829 & 37.4777 & 56.6452 & 1.0084 & 1.7867 \\
P & 31.7832 & 10.1739 & 13.4534 & 113.1141 & 68.3534 & 5.1661 & 2.4081 \\
\hline
\end{tabular}




\section{Phosphorus cleaving}

Table S13: $P_{\text {CleaveMax }}$ per growing season for the limestone grassland, and the amount of P cleaved from the SOP pool in 2020 under different nutriment treatments.

\begin{tabular}{ccc}
\hline Treatment & $\begin{array}{c}\boldsymbol{P}_{\text {cleaveMax }}\left(\mathbf{g ~ m}^{-\mathbf{2}} \text { per growing }\right. \\
\text { season) }\end{array}$ & P cleaved in $\mathbf{2 0 2 0}\left(\mathbf{g ~ m}^{-\mathbf{2}}\right)$ \\
\hline ON & 0.0316 & 0.0632 \\
LN & 0.0316 & 0.0632 \\
HN & 0.0316 & 0.0632 \\
P & 0.0316 & 0.0000 \\
\hline
\end{tabular}

ON
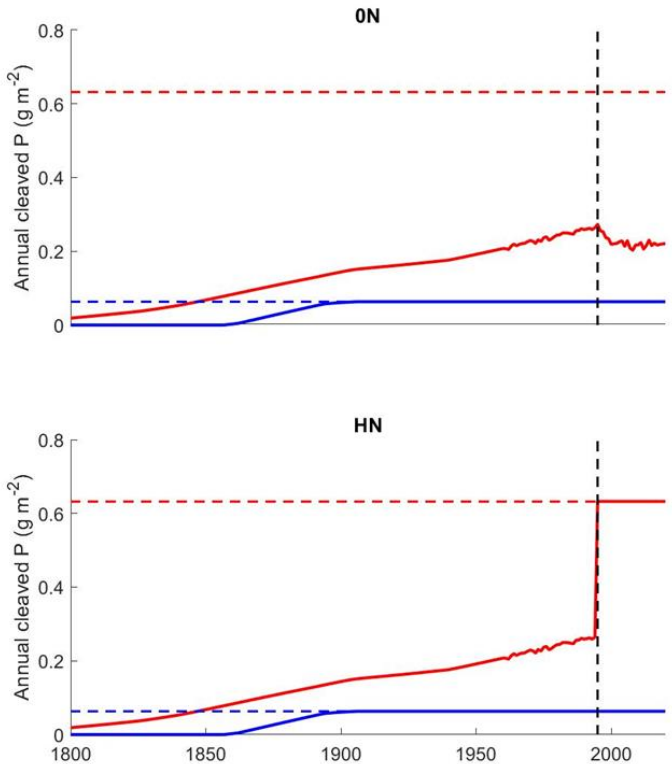

LN
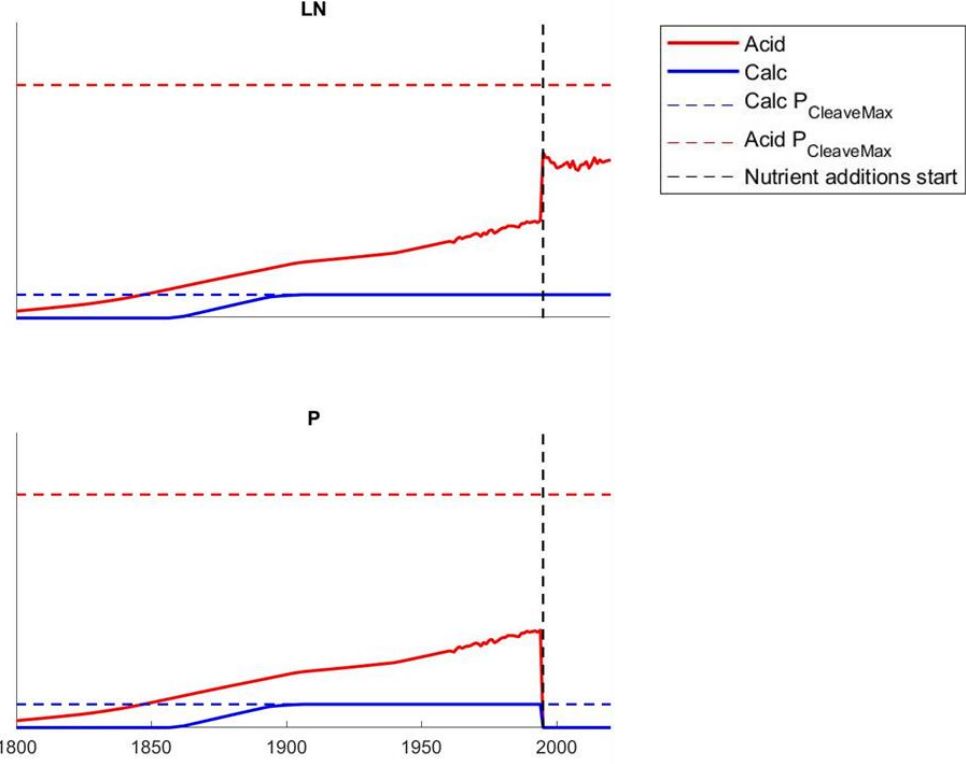

Figure S1: A time series showing the annual amount of $\mathrm{P}$ cleaved from the SOP pool by the modelled acidic and limestone (Calc) grasslands in the a) $\mathrm{ON}$, b) $\mathrm{LN}, \mathrm{c}$ ) HN and d) P treatments. The horizontal blue and red dashed lines represent the maximum potential cleaved SOP of the acidic and limestone grasslands respectively, summed across both growing seasons. The vertical dashed line signals the start of the experimental period of nutrient manipulation. Where the solid line meets the dashed line of the same colour, plant P demand exceeds plant $\mathrm{P}$ acquisition ability and hence the ecosystem is P-limited. 
The effect of $\mathbf{N}$ deposition alone - AGB_C, SOC, SON, SOP from 1800 - 2020

Table S14: Differences in nutrient pools (C, N, P and AGB_C are the same variables as in Tables S4 and S5) between 1800 (Y_1800) and the present (Y_2020) to show the effects of $N$ deposition through time. Rows in bold highlight the $\mathrm{ON}$ control treatments to show the effects of $\mathrm{N}$ deposition in isolation. As with Tables $\mathrm{S} 4$ and $\mathrm{S} 5$, the absolute and percentage difference are shown, and all data aside from percentage difference are in grams per metre squared.

\begin{tabular}{|c|c|c|c|c|c|c|}
\hline Nutrient & Grassland & Treatment & Y_1800 & Y_2020 & Diff & Per_Diff \\
\hline 'C' & 'Acid' & 'ON' & 3839.63 & 6987.28 & 3147.65 & 81.98 \\
\hline 'C' & 'Acid' & 'LN' & 3839.63 & 7789.21 & 3949.57 & 102.86 \\
\hline 'C' & 'Acid' & 'HN' & 3839.63 & 8425.72 & 4586.09 & 119.44 \\
\hline 'C' & 'Acid' & 'P' & 3839.63 & 6987.28 & 3147.65 & 81.98 \\
\hline 'N' & 'Acid' & 'ON' & 229.09 & 399.99 & 170.90 & 74.60 \\
\hline 'N' & 'Acid' & 'LN' & 229.09 & 438.88 & 209.79 & 91.58 \\
\hline 'N' & 'Acid' & 'HN' & 229.09 & 546.55 & 317.46 & 138.57 \\
\hline 'N' & 'Acid' & 'P' & 229.09 & 399.99 & 170.90 & 74.60 \\
\hline 'P' & 'Acid' & 'ON' & 32.65 & 38.16 & 5.51 & 16.87 \\
\hline 'P' & 'Acid' & 'LN' & 32.65 & 36.49 & 3.85 & 11.78 \\
\hline 'P' & 'Acid' & 'HN' & 32.65 & 34.70 & 2.05 & 6.29 \\
\hline 'P' & 'Acid' & 'P' & 32.65 & 67.42 & 34.77 & 106.50 \\
\hline 'AGB_C' & 'Acid' & 'ON' & 163.12 & 573.25 & 410.13 & 251.43 \\
\hline 'AGB_C' & 'Acid' & 'LN' & 163.12 & 780.49 & 617.37 & 378.47 \\
\hline 'AGB_C' & 'Acid' & 'HN' & 163.12 & 926.96 & 763.84 & 468.27 \\
\hline 'AGB_C' & 'Acid' & 'P' & 163.12 & 573.25 & 410.13 & 251.43 \\
\hline 'C' & 'Lime' & 'ON' & 4607.99 & 6613.41 & 2005.42 & 43.52 \\
\hline 'C' & 'Lime' & 'LN' & 4607.99 & 6583.32 & 1975.33 & 42.87 \\
\hline 'C' & 'Lime' & 'HN' & 4607.99 & 6523.45 & 1915.47 & 41.57 \\
\hline 'C' & 'Lime' & 'P' & 4607.99 & 7015.10 & 2407.12 & 52.24 \\
\hline 'N' & 'Lime' & 'ON' & 289.38 & 441.27 & 151.89 & 52.49 \\
\hline 'N' & 'Lime' & 'LN' & 289.38 & 469.48 & 180.10 & 62.24 \\
\hline 'N' & 'Lime' & 'HN' & 289.38 & 507.64 & 218.26 & 75.42 \\
\hline 'N' & 'Lime' & 'P' & 289.38 & 440.33 & 150.95 & 52.16 \\
\hline 'P' & 'Lime' & 'ON' & 43.72 & 56.95 & 13.23 & 30.26 \\
\hline 'P' & 'Lime' & 'LN' & 43.72 & 56.85 & 13.13 & 30.03 \\
\hline 'P' & 'Lime' & 'HN' & 43.72 & 56.65 & 12.92 & 29.56 \\
\hline 'P' & 'Lime' & 'P' & 43.72 & 68.35 & 24.63 & 56.34 \\
\hline 'AGB_C' & 'Lime' & 'ON' & 192.34 & 434.61 & 242.26 & 125.96 \\
\hline 'AGB_C' & 'Lime' & 'LN' & 192.34 & 424.05 & 231.71 & 120.47 \\
\hline 'AGB_C' & 'Lime' & 'HN' & 192.34 & 403.05 & 210.71 & 109.55 \\
\hline 'AGB_C' & 'Lime' & 'P' & 192.34 & 530.37 & 338.03 & 175.75 \\
\hline
\end{tabular}


Responses to nutrient treatments - changes in AGB_C, SOC, SON and SOP between 1995 - 2020

Table S15: Responses of nutrient pools to experimental nutrient additions (ON, LN, HN and P). 'Value' shows the modelled value for the size of the nutrient pool in the year 2020. Absolute and percentage difference are the difference between the size of the nutrient pool in 1995 and the size in 2020 (Value), hence a positive value is an increase. This table contains data for the acidic grassland. All data are in grams per metre squared.

\begin{tabular}{ccccc}
\hline Nutrients & Treatment & Value & Absolute difference & Percent difference \\
\hline 'C' & 'ON' & 6987.28 & 0.00 & 0.00 \\
'C' & 'LN' & 7789.21 & 801.92 & 11.48 \\
'C' & 'HN' & 8425.72 & 1438.44 & 20.59 \\
'C' & 'P' & 6987.28 & 0.00 & 0.00 \\
'N' & 'ON' & 399.99 & 0.00 & 0.00 \\
'N' & 'LN' & 438.88 & 38.89 & 9.72 \\
'N' & 'HN' & 546.55 & 146.56 & 36.64 \\
'N' & 'P' & 399.99 & 0.00 & 0.00 \\
'P' & 'ON' & 38.16 & 0.00 & 0.00 \\
'P' & 'LN' & 36.49 & -1.66 & -4.35 \\
'P' & 'HN' & 34.70 & -3.45 & -9.05 \\
'P' & 'P' & 67.42 & 29.26 & 76.69 \\
'AGB_C' & 'ON' & 573.25 & 0.00 & 0.00 \\
'AGB_C' & 'LN' & 780.49 & 207.24 & 36.15 \\
'AGB_C' & 'HN' & 926.96 & 353.71 & 61.70 \\
'AGB_C' & 'P' & 573.25 & 0.00 & 0.00 \\
\hline
\end{tabular}


Table S16: Responses of nutrient pools to experimental nutrient additions (ON, LN, HN and P). 'Value' shows the modelled value for the size of the nutrient pool in the year 2020. Absolute and percentage difference are the difference between the size of the nutrient pool in 1995 and the size in 2020 (Value), hence a positive value is an increase. This table contains data for the limestone grassland. All data are in grams per metre squared.

\begin{tabular}{ccccc}
\hline Nutrients & Treatment & Value & Absolute difference & Percent difference \\
\hline 'C' & 'ON' & 6613.41 & 0.00 & 0.00 \\
'C' & 'LN' & 6583.32 & -30.09 & -0.46 \\
'C' & 'HN' & 6523.45 & -89.96 & -1.36 \\
'C' & 'P' & 7015.10 & 401.69 & 6.07 \\
'N' & 'ON' & 441.27 & 0.00 & 0.00 \\
'N' & 'LN' & 469.48 & 28.20 & 6.39 \\
'N' & 'HN' & 507.64 & 66.37 & 15.04 \\
'N' & 'P' & 440.33 & -0.95 & -0.21 \\
'P' & 'ON' & 56.95 & 0.00 & 0.00 \\
'P' & 'LN' & 56.85 & -0.10 & -0.18 \\
'P' & 'HN' & 56.65 & -0.30 & -0.54 \\
'P' & 'P' & 68.35 & 11.40 & 20.02 \\
'AGB_C' & 'ON' & 434.61 & 0.00 & 0.00 \\
'AGB_C' & 'LN' & 424.05 & -10.56 & -2.43 \\
'AGB_C' & 'HN' & 403.05 & -31.56 & -7.26 \\
'AGB_C' & 'P' & 530.37 & 95.77 & 22.04 \\
\hline
\end{tabular}




\section{Supplementary references}

Chapin, F. S., Matson, P. A., Mooney, H. A., (2011) Principles of terrestrial ecosystem ecology. Springer, New York

Davies, J. A. C., E. Tipping, E. C. Rowe, J. F. Boyle, E. G. Pannatier, and V. Martinsen (2016b), Longterm $\mathrm{P}$ weathering and recent $\mathrm{N}$ deposition control contemporary plant-soil $\mathrm{C}, \mathrm{N}$, and $\mathrm{P}, \mathrm{Global}$ Biogeochemical Cycles, 30(2), 231-249. https://doi.org/10.1002/2015GB005167

Harris, D., Horwáth, W. R., van Kessel, C., (2001), Acid fumigation of soils to remove carbonates prior to total organic carbon or CARBON-13 isotopic analysis, Soil Science Society of America Journal, 65, 1853 - 1856, https://doi.org/10.2136/sssaj2001.1853

Hedges, J. I., Stern, J. H., (1984), Carbon and nitrogen determinations of carbonate-containing solids, Limnology and Oceanography, 29, 657 - 663, https://doi.org/10.4319/lo.1984.29.3.0657

Horswill, P., O. O'Sullivan, G. K. Phoenix, J. A. Lee, and J. R. Leake (2008), Base cation depletion, eutrophication and acidification of species-rich grasslands in response to long-term simulated nitrogen deposition, Environmental Pollution, 155(2), 336-349.

https://doi.org/10.1016/j.envpol.2007.11.006

Morecroft, M. D., E. K. Sellers, and J. A. Lee (1994), AN EXPERIMENTAL INVESTIGATION INTO THE EFFECTS OF ATMOSPHERIC NITROGEN DEPOSITION ON 2 SEMINATURAL GRASSLANDS, Journal of Ecology, 82(3), 475-483. https://doi.org/10.2307/2261256

Phoenix, G. K., Booth, R. E., Leake, J. R., Read, D. J., Grime, P. J., Lee, J. A., (2003), Effects of enhanced nitrogen deposition and phosphorus limitation on nitrogen budgets of semi-natural grasslands, Global Change Biology, 9, 1309 - 1321, https://doi.org/10.1046/j.1365-2486.2003.00660.x

Taylor, D M, et al. (1994), Radiocarbon-dated Holocene pollen and ostracod sequences from barrage Tufa- dammed fluvial systems in the White Peak, Derbyshire, UK, The Holocene, 4, 356-364 https://doi.org/10.1177/095968369400400403 